\title{
Resenha: Psicopathologia II - Semiologia Clínica: Investigação Teórico-Clínica das Síndromes Psicopatológicas Clássicas
}

\author{
José Newton Garcia de Araújo ${ }^{1}$ \\ Pontifícia Universidade Católica de Minas Gerais
}

\section{Book Review: Psicopathology II - Clinical Semiology: Theoretical-Clinical Investigation of the Classic Psychopathological Syndromes}

$\mathrm{Na}$ introdução de sua obra, Francisco Martins nos adverte que a psicopatologia clínica é "uma espécie de enfant terrible da sua mãe, a Medicina", uma criança que encanta e inferniza, a um só tempo, dada a sua complexidade e rebeldia aos ditames lógicos adotados pela mãe. Por isso mesmo, o tema nos remete a uma realidade minada de agressividade, visitada pela violência e pela morte, um "inimigo" difícil de se combater, pois com sua "tendência para camaleão" não se deixa localizar facilmente. Afinal, a psicopatologia é o campo dos fenômenos multifacetados que se mostram ora como sinal ou sintoma, ora como síndrome ou queixa. $\mathrm{O}$ autor entra nesse campo investigativo com novas armas, fugindo à mera caça dos signos clínicos, como na abordagem clássica dos fenômenos patológicos. Ele opta pela "descrição de constelações", antes de ir aos sintomas, aos sinais ou a possíveis causalidades. Sua opção metodológica se ancora num conjunto de informações que vão além da semiologia tradicional, dando vez a um referencial que ele denomina semiologia clínica sindrômica.

Se a síndrome é um complexo expressivo que pode desvelar o ser do paciente, Francisco Martins propõe que a atividade semiológica deva se interessar não propriamente por aquilo que alguém tem, mas pelo que alguém é. Esse tipo de pensar clínico sabe que a causalidade biológica tem “outras irmãs". Daí ele se valer de outra lógica, de outras práticas, nascidas das ciências humanas e sociais. Assim, mesmo reconhecendo o psiquiatra como "o principal criador, usuário e propagador" deste saber, o autor, psicólogo e também psiquiátrica de formação, propõe que o termo psiquiatra seja extensivo a todos os profissionais que compartilham e se beneficiam da semiologia sindrômica. Para tanto, ele lança mão de diversas teorias semióticas, como a de Peirce, a fenomenologia de Husserl, a lingüística estrutural e o estruturalismo, a hermenêutica de Ricoeur, a neopragmática erigida sob as influências de Husserl, Austin e Searle. Esse leque de ferramentas teóricas seria, então, uma alternativa às limitações e fracassos do "absolutismo semiológico" ou de uma "semiologia geral" petrificada.

A obra se estrutura em quatro capítulos que se interpenetram, numa arquitetura, ao mesmo tempo sólida e caleidoscópica, já que maneja uma luminosa interpenetração do saber médico-psiquiátrico com aqueles do psicólogo, do

1 Endereço: Pontifícia Universidade Católica de Minas Gerais, Instituto de Psicologia, Av. Dom José Gaspar 500, Belo Horizonte, MG, Brasil 30535-610.E-mail: jinga@uol.com.br antropólogo, do psicanalista, dos sociólogos, historiadores e filósofos, todos eles em diálogo com as artes, a mitologia, a cultura popular.

O primeiro capítulo, intitulado A semiologia médica, é uma revisão da literatura clássica, que dá passagem, no capítulo seguinte, à diferente ordem de fenômenos psiquiátricos, ou seja, A especificidade da semiologia psiquiátrica sindrômica. Segue-se uma essencial distinção que fundamenta a perspectiva crítica do autor: de um lado, As síndromes psicopatológicas dominadas por signos unívocos (capítulo III); de outro lado, As síndromes psicopatológicas permeadas por signos equívocos (capítulo IV). Nestas últimas, o leitor toma contato justamente com o complexo terreno das síndromes psicoafetivas, sejam elas neuróticas, perversas, delirantes ou alucinatórias, passando pelas doenças psicossomáticas, pelas drogadições, alcoolismo e mesmo pelo suicídio.

$\mathrm{Na}$ conclusão, Francisco Martins reafirma a sua postura crítica, através da qual concebe a atividade semiológica, como independente da regionalização do saber centrada na semiologia médico-psiquiátrica. Aponta também para os limites da semiologia apoiada apenas nos signos unívocos, dada a sobreposição entre os signos, ditos objetivos, e os não objetiváveis. Daí a necessidade de se entender a clínica cotidiana numa ótica que contemple a "injunção comunicacional simbólica”. Trata-se, aqui, de uma prática clínica que leva o próprio paciente a elaborar seus signos, retirando-o de um lugar passivo. Isso exige que se realizem atos com a linguagem, desde que o paciente não seja apenas mero narrador de algo ocorrido, à mercê do diagnóstico do médico. Afinal, em todo processo terapêutico, é essencial que o sujeito "possa participar com sua poesia, com seu saber".

$\mathrm{O}$ autor mostra também que, para além da semiologia médica clássica, as demais práticas semiológicas se ocupam não só em colher os signos, mas em procurar saber como eles são produzidos. Eis aí a ruptura entre a semiologia dos signos unívocos, própria do campo biológico ou das ciências da natureza, e a outra dos signos equívocos, inerente aos campos psíquico e cultural, ou seja, uma ruptura que marca a passagem do homo natura ao homo cultura. Não se trata mais de buscar, na perspectiva "causalista" uma fidedignidade entre sintomas e doenças, vistas como um referente real, mas de tomar os signos como portadores de sentido e de história. Francisco Martins encerra o seu texto com um "final em forma de esperança", uma vez que a prática semiológica que propõe - mais completa, complexa e humana - fundada na heterogeneidade fenomenológica dos signos, possibilita uma efetiva expansão do universo clínico. 
Se a abordagem do autor, fundada em densidade teórica e erudição, discute os conceitos clínicos numa ótica eminentemente crítica, ela não deixa de ser - e aí está mais um mérito essencial desta obra - um texto didático. Chama a atenção a concepção gráfica do livro, com sua profusão de vinhetas, tabelas, diagramas e ilustrações, o que evidencia o cuidado do autor em torná-lo acessível ao aluno ou a todo profissional da área. Tal zelo é completado por um rico Glossário de termos psiquiátricos clássicos e de uma importante ferramenta de aprendizagem: Estudos dirigidos e instrução programada com respostas.

Se não soubéssemos que Francisco Martins lançará, brevemente, um novo volume de sua Coleção Psicopathologia, poderíamos afirmar que apenas este tomo seria suficiente para se firmar como uma obra de referência, ou seja, um tratado de psicopatologia que já nasce como clássico.

\section{Referência}

Martins, F. (2003). Psicopathologia II - semiologia clínica: Investigação teórico-clínica das síndromes psicopatológicas clássicas. Brasília: ABRAFIPP/Laboratório de Psicanálise e Psicopatologia, UnB.

\section{MUDANÇA DE ENDEREÇO}

Se você está mudando de endereço, por favor, notifique Psicologia: Teoria e Pesquisa. Ocasionalmente, assinantes e autores comunicam tardiamente mudança de endereço gerando dificuldades na entrega de nossa revista ou de outras correspondências. Informe imediatamente, se possível com antecedência, qualquer mudança de domicílio para:

Universidade de Brasília - Instituto de Psicologia

Revista Psicologia: Teoria e Pesquisa

Secretaria de Divulgação

70910-900 Brasília DF

Mudanças de endereço poderão também ser comunicadas através do correio eletrônico revptp@unb.br ou do telefone e fax 55612746455 . 